\title{
Study on the status and effectiveness of coastal wetland utilization in Duy Xuyen district, Quang Nam province
}

\author{
Đánh giá thực trạng và hiệu quả sủ dụng đất ngập nước ven biển trên địa bàn \\ huyện Duy Xuyên, tỉnh Quảng Nam \\ Research article
}

Nguyen Hoang Khanh Linh ${ }^{1 *}$, Trinh Ngan Ha ${ }^{1}$, Nguyen Quang Tan ${ }^{2}$

${ }^{I}$ Faculty of Land Resources and Agricultural Environment, Hue University of Agriculture and Forestry, Hue University. Address: 102 Phung Hung, Hue City, Vietnam; ${ }^{2}$ Faculty of Environmental and Life science, Okayama University. Address: 2-1-1 Tsushima-naka, Kita-ku, Okayama City, Japan

\begin{abstract}
This paper aims to assess the current status and effectiveness of coastal wetland utilization in Duy Xuyen district, Quang Nam province, and to propose solutions to improve land use and conserve the existing wetlands of the locality. Research results show that there are five types of wetlands in Duy Xuyen district: wetlands with tidal forests, streams, freshwater ponds, aquaculture ponds, and irrigated land. The wetland areas in Duy Xuyen district are mainly distributed in 3 communes: Duy Thanh, Duy Nghia and Duy Vinh and there is a noticeable decrease in the period from 2010 to 2016. The calculated results show that the total economic value of wetlands in the study area includes: direct use value is $41,276,949,000 \mathrm{VND}$ /year (accounting for $99.61 \%$ ), non-use value is $162,855,000 \mathrm{VND} /$ year (accounting for $0.39 \%$ ). In which, the social and environmental economic values of wetland use types are totally different.
\end{abstract}

Bài báo này nhằm muc đỉch đánh giá thực trạng và hiệu quả sủ dụng đất ngập nuớc ven biển trên địa bàn huyện Duy Xuyên, tỉnh Quảng Nam, trên co sở đó đề xuất nhũng giải pháp nhằm nâng cao hiệu quả sủ dụng và bảo tồn diện tích đất ngập nước hiện có của địa phuong. Kết quả nghiên cứu cho thấy, trên địa bàn huyện Duy Xuyên có 5 kiểu đất ngập nuớc: vùng đất ngập nuớc có rừng gian triều, sông suối, vùng nước ngọt, ao nuôi trồng thủy sản, đất được tưới tiêu. Diện tích đất ngập nước trên địa bàn huyện Duy Xuyên chủ yếu phân bố ở 3 xã : Duy Thành, Duy Nghĩa và Duy Vinh và có sư biến động giảm rõ rệt tù̀ năm 2010 đến năm 2016. Kết quả điều tra cho thấy tổng giá trị kinh tế của đất ngập nước trên địa bàn nghiên cứu bao gồm: giá trị sử dụng trực tiếp (41,276,949,000 đồng/năm, chiếm 99.61\%), giá trị phi sủ dụng (chiếm 0.39\% đạt 162,855,000 đồng/năm). Trong đó, hiệu quả xã hội và môi truờng giũa các kiểu sử dụng đất ngập nuớc không đồng đều.

Keywords: biodiversity, direct use value, wetland

\section{Introduction}

Wetland is one of the most important ecosystems on Earth. In Vietnam, the wetland has an area of approximately $5,810,000$ ha, accounting for about $8 \%$ of all wetlands in Asia (Thang, 2006). According to a report on the status of wetlands in Vietnam after 15 years of implementation Ramsar Convention: "Wetland and its biodiversity have been associated with the Vietnamese people throughout thousand years of history. The civiliza- tion of the Vietnamese was dubbed as the wet rice civilization" (Vietnam Environment Protection Agency, 2005).

As the natural conditions, the wetland in Quang Nam has a significant proportion of the total wetland area in the central coastal region of Vietnam. However, the wetland areas have been gradually lost and strong degraded, which raised an alarming concern. Accordingly, the management and use of existing wetlands in Duy Xuyen district, Quang Nam province are facing with many difficulties and inadequacies. Management of utilization and invento- 
ry of wetlands as the economic, social and environmental values have not been paid much attention. Besides, the exploitation and use of marsh are lack of synchronous planning. Many wetland areas have been converted to use for other purposes, which affected and caused pollution to water resources. Based on the above issues, the research was conducted to improve the effectiveness in managing and exploiting wetland resources in Duy Xuyen district, Quang Nam province.

\section{Methodologies}

\subsection{Selecting study sites}

Studies were carried out in Duy Xuyen district, Quang Nam province, which includes 13 communes and 01 district town. However, the wetland distributes only in Duy Thanh, Duy Nghia, and Duy Vinh. Therefore, these communes were selected to focus on surveying and evaluation because of their large area, broad distribution, many exploitations and use of wetland.

\subsection{Surveying and collecting data}

+ Collecting secondary data from reports such as the annual land inventory of Duy Xuyen district; the land use planning up to 2020; the result of first 5year land use plan (2011 - 2015) of Duy Xuyen district; the district's statistical yearbooks.

+ Collecting primary data by interviewing livelihoods of local people based on wetland resources (production costs, labor, productivity, plant varieties, animal breeds, etc.) for the assessment of economic value and proposal of measures to manage wetland in the study area. Selection of surveyed households was conducted on a random basis. The sample size was determined according to the formula of Cochran (Duc, 2017).

$$
n=\frac{z^{2} p(1-q)}{e^{2}}
$$

In which:

$n$ : number of samples to be calculated

$z$ : the value associated with the level of confidence (if the reliability is $95 \%, \mathrm{z}=1.96) ; p$ : the estimate $\%$ of the total (usually, $\mathrm{p}$ is set to 0.5 in previous studies); $e$ : error (the smaller the error, the larger the sample size). With 7,438 households in the study area (within three communes), $95 \%$ of the reliability and $10 \%$ of the allowable error $e$. In this study, 95 households were selected to survey (Table 1).

\section{Table 1. Questionnaire structure}

\begin{tabular}{clccc} 
No & Commune & $\begin{array}{c}\text { Total } \\
\text { households }\end{array}$ & $\begin{array}{c}\text { Sample } \\
\text { size }\end{array}$ & $\begin{array}{c}\text { Percentage } \\
(\%)\end{array}$ \\
\hline 1 & Duy Thanh & 2,028 & 25 & 26.32 \\
2 & Duy Nghia & 2,795 & 35 & 36.84 \\
3 & Duy Vinh & 2,615 & 35 & 36.84 \\
& Sum & $\mathbf{7 , 4 3 8}$ & $\mathbf{9 5}$ & $\mathbf{1 0 0}$
\end{tabular}

Besides, comments from scientists, provincial / district /commune People's Committee, experienced managers of the fisheries, agriculture and tourism sectors, staffs of Department of Natural Resources and Environment, Eco- nomic Division, Agricultural and Forestry Extension Station in the study area were proposed for sustainable development for wetlands.

\subsection{Market price valuation approach}

Market price method is used to estimate production surplus by cultivating and harvesting products from wetland areas to calculate the direct use value of wetland in supplying commodities for local people. Mostly, the producer surplus is the difference between the selling price of the product and the cost of producing, representing the contribution of wetlands to the value of production. Producer surplus is calculated by the following formula:

In which:

$$
\mathrm{V}_{\mathrm{i}}=\sum\left(\mathrm{P}_{\mathrm{i}} * \mathrm{Q}_{\mathrm{i}}-\mathrm{C}_{\mathrm{i}}\right)
$$

$\mathrm{V}_{\mathrm{i}}$ : Production surplus of $i^{\text {th }}$ product

$\mathrm{P}_{\mathrm{i}}$ : Price of $i^{\text {th }}$ product

Qi: Quantity of exploited product $i$

$\mathrm{Ci}$ : Costs related to the process of mining, manufacturing $i^{\text {th }}$ product

Market price valuation approach is based on the level of "willingness to pay" which indicates the prices of goods and services traded on the market. Therefore, it is used to evaluate direct use values of wetland (Truong, 2008; Lan, 2013).

\subsection{Wetland classification system}

Recently, many wetland classification system definitions have been introduced due to wetland characteristics and national perceptions of wetland management. In this study, the wetland classification system proposed by Hoang Van Thang and Le Dien Duc is used to identify wetland in Duy Xuyen district (Thang, 2006). This classification system is chosen because of its advantages, which covers all types of wetlands under the Ramsar Convention and limits the disadvantages that previous classification systems (not reflect all kinds of swamps of Vietnam, too simple or too detailed...).

\section{Results and Discussions}

\subsection{The status of wetland in Duy Xuyen dis- trict}

Based on the wetland classification system of Hoang Van Thang and Le Dien Duc (2006), the results of this study indicate that there are five types of wetlands within Duy Xuyen district. It includes wetlands with intertidal forests; the rivers/streams/creeks with regular water; ponds/puddles with fresh water (under 8ha), lagoons and wetlands with waterlogged vegetation in the growing season; aquaculture ponds; irrigated land (Table 2).

By using collected data and field survey, the distribution of wetland in Duy Xuyen district is identified and shown in Table 3. The results indicate that the total area of wetland in Duy Thanh commune is $\mathbf{5 3 5 . 0 8}$ ha, accounting for $56.56 \%$ of the natural area of Duy Thanh commune. The 
entire area of wetland in Duy Vinh commune is 544.94 ha, accounting for $53.53 \%$ of the natural area of Duy Vinh. Whereas, Duy Nghia commune has only 311.92 ha of wetland, accounting for $21.28 \%$ of the total area of Duy Nghia commune.

It shows that the distribution of wetland types within three communes is entirely different. According to statistic data, the type AII2 (rivers, canals, streams) mainly occupy in Duy Vinh and Duy Nghia with an area of 273.47 ha (50.18\% of wetland) and 148.6 ha (47.64\% of wetland), respectively. However, the highest occupied structure in the wetland area at Duy Thanh commune is type BIV2 (rice land) with an area of 355.61 ha $(66.46 \%$ of wetland). The lowest occupied structure of wetland, accounting for $0.35 \%$ in Duy Thanh Commune (1.86 ha) and $0.75 \%$ in Duy Nghia Commune (2.35 ha) is type AI9 (wetland with mangrove forest, swamps water coconut). Whereas, Duy Vinh commune has the lowest land area of type AII10 (with special water surface) accounting for $0.95 \%$, occupying 5.18 ha.

The results show that the area of wetland within three studied communes is $1,391.95$ ha accounting for $40.58 \%$ the total area of Duy Thanh, Duy Nghia, and Duy Vinh. In which:
+ Type AI9 (Mangrove forests in the wetland) occupy with a minimum area of 17.39 ha, accounting for $1.25 \%$ of wetland in three communes. It is mainly located along rivers and some scattered spaces in residential areas and paddy fields.

+ Type AII2 (Rivers, canals, and streams) is belonging to the non-agricultural land and cover an area of 574.82 ha, accounting for $41.3 \%$ of wetland in three communes. Because there are many large rivers crossed the area, such as Thu Bon, Truong Giang, Ba Ren and Ly Ly streams.

+ Type AII10 (Special water surface) distributes with the total area of 17.48 ha, accounting for $1.26 \%$ of wetland in three communes, including ponds and lakes intermingled with residential areas and production areas.

+ Type BIII1 (Aquaculture land) covers an area of 132.21 ha, accounting for $9.5 \%$ of wetland in three communes. Land for aquaculture is mainly scattered along the rivers.

+ Type BIV2 (Rice land) is the most significant area with $650.05 \mathrm{ha}$, accounting for $46.7 \%$ of wetland in three communes. It covers mainly on large fields with good fertility and effective irrigation, which could give high yields for rice crop.

Table 2. Types of wetland in Duy Xuyen district

\begin{tabular}{|c|c|c|c|}
\hline $\begin{array}{l}\text { Type of Wet- } \\
\text { land }\end{array}$ & $\begin{array}{c}\text { Sub-Type of } \\
\text { Wetland }\end{array}$ & Code & Definition \\
\hline \multirow{3}{*}{$\begin{array}{l}\text { A } \\
\text { AREA WITH } \\
\text { NATURAL } \\
\text { WATER }\end{array}$} & $\begin{array}{c}\text { I } \\
\text { Coastal wetlands }\end{array}$ & A I 9 & $\begin{array}{l}\text { Wetlands with intertidal forests, including mangrove } \\
\text { forests, freshwater marshes, and freshwater ponds }\end{array}$ \\
\hline & \multirow[b]{2}{*}{$\begin{array}{l}\text { II } \\
\text { Inland wetland }\end{array}$} & A II 2 & $\begin{array}{l}\text { The rivers/ streams/creeks with regular water, includ- } \\
\text { ing waterfalls }\end{array}$ \\
\hline & & A II 10 & $\begin{array}{l}\text { Ponds/puddles with fresh water (under } 8 \text { ha); lagoons } \\
\text { and wetlands with waterlogged vegetation in the grow- } \\
\text { ing season }\end{array}$ \\
\hline $\begin{array}{c}\text { B } \\
\text { AREA WITH }\end{array}$ & $\begin{array}{c}\text { III } \\
\text { Sea and coastal } \\
\end{array}$ & B III 1 & Aquaculture ponds (e.g., shrimp/fish ponds) \\
\hline $\begin{array}{l}\text { ARTIFICIAL } \\
\text { WATER }\end{array}$ & $\begin{array}{l}\text { IV } \\
\text { Inland }\end{array}$ & B IV 2 & $\begin{array}{l}\text { Irrigated land, including irrigation canals and rice } \\
\text { fields }\end{array}$ \\
\hline
\end{tabular}

Table 3. Distribution of wetland in the study area

\begin{tabular}{|c|c|c|c|c|c|c|c|}
\hline \multirow[b]{2}{*}{ Code } & \multirow[b]{2}{*}{ Types } & \multicolumn{2}{|c|}{ Duy Thanh } & \multicolumn{2}{|c|}{ Duy Vinh } & \multicolumn{2}{|c|}{ Duy Nghia } \\
\hline & & $\begin{array}{c}\text { Area } \\
\text { (ha) }\end{array}$ & $\begin{array}{l}\text { Percent } \\
(\%)\end{array}$ & $\begin{array}{c}\text { Area } \\
\text { (ha) }\end{array}$ & $\begin{array}{l}\text { Percent } \\
(\%)\end{array}$ & $\begin{array}{l}\text { Area } \\
\text { (ha) }\end{array}$ & $\begin{array}{l}\text { Percent } \\
(\%)\end{array}$ \\
\hline A I 9 & $\begin{array}{l}\text { Wetlands with intertidal for- } \\
\text { ests, the water coconut forest }\end{array}$ & 1.86 & 0.35 & 13.18 & 2.42 & 2.35 & 0.75 \\
\hline A II 2 & Rivers, canals, streams & 152.75 & 28.55 & 273.47 & 50.18 & 148.60 & 47.64 \\
\hline $\begin{array}{c}\text { A II } \\
10\end{array}$ & $\begin{array}{l}\text { Land with the specialized wa- } \\
\text { ter surface }\end{array}$ & 3.14 & 0.59 & 5.18 & 0.95 & 9.16 & 2.94 \\
\hline B III 1 & Aquaculture land & 21.72 & 4.06 & 83.96 & 15.41 & 26.53 & 8.51 \\
\hline B IV 2 & Arable land & 355.61 & 66.46 & 169.16 & 31.04 & 125.28 & 40.16 \\
\hline & Sum & 535.08 & 100 & 544.95 & 100 & 311.92 & 100 \\
\hline
\end{tabular}

\subsection{The change of wetland in Duy Xuyen district}

As the local land-use data has not been updated regularly and on time, it is somewhat difficult to assess the causes of wetland changes in the extended period. Therefore, in this study, we decide to access the difference in the area of the wetland based on available collected data in Duy Xuyen district, from 2010 to 2016 (Table 4). 
Table 4. Wetland land use change in Duy Xuyen district from 2010 to 2016

\begin{tabular}{|c|c|c|c|c|c|c|c|c|c|c|}
\hline \multirow[b]{2}{*}{ Code } & \multirow[b]{2}{*}{ Type } & \multicolumn{3}{|c|}{ Duy Thanh } & \multicolumn{3}{|c|}{ Duy Vinh } & \multicolumn{3}{|c|}{ Duy Nghia } \\
\hline & & $\begin{array}{l}\text { Area } \\
2010 \\
\text { (ha) }\end{array}$ & $\begin{array}{c}\text { Area } \\
2016 \\
\text { (ha) }\end{array}$ & $\begin{array}{l}\text { Change } \\
\text { (ha) }\end{array}$ & $\begin{array}{l}\text { Area } \\
2010 \\
\text { (ha) }\end{array}$ & $\begin{array}{l}\text { Area } \\
2016 \\
\text { (ha) }\end{array}$ & $\begin{array}{l}\text { Change } \\
\text { (ha) }\end{array}$ & $\begin{array}{l}\text { Area } \\
2010 \\
\text { (ha) }\end{array}$ & $\begin{array}{c}\text { Area } \\
2016 \\
\text { (ha) }\end{array}$ & $\begin{array}{c}\text { Change } \\
\text { (ha) }\end{array}$ \\
\hline & Total & 942.56 & 946.08 & 3.52 & 882.51 & 1018.11 & 135.6 & 1344.33 & 1465.56 & 121.23 \\
\hline B IV 2 & Rice land & 352.07 & 355.61 & 3.54 & 147.13 & 169.16 & 22.03 & 142.94 & 125.28 & -17.66 \\
\hline B III 1 & Aquaculture land & 14.88 & 21.72 & 6.84 & 60.03 & 83.96 & 23.93 & 29.49 & 26.53 & -2.96 \\
\hline A II 2 & $\begin{array}{l}\text { Rivers, canals, } \\
\text { streams }\end{array}$ & 164.34 & 152.75 & -11.59 & 236.01 & 273.47 & 37.46 & 293.51 & 148.6 & 144.91 \\
\hline A II 10 & $\begin{array}{l}\text { Land with the spe- } \\
\text { cialized water sur- } \\
\text { face }\end{array}$ & 9.25 & 3.14 & -6.11 & 5.04 & 5.18 & 0.14 & 18.14 & 9.16 & -8.98 \\
\hline A I 9 & $\begin{array}{l}\text { Wetlands with } \\
\text { mangrove forests, } \\
\text { coconut water }\end{array}$ & 3.2 & 1.86 & -1.34 & 12.3 & 13.18 & 0.88 & 6.4 & 2.3 & -4.1 \\
\hline
\end{tabular}

According to statistic data, the total natural area of Duy Xuyen district in 2016 was $30,875.03$ ha. It increased 965.98 ha, compared to the year 2010 with an area of $29,909.5$ ha. The reasons for such change are due to the application of high technology in automatically calculating and inventorying within administrative boundaries, which increase the accuracy of statistic data. Accordingly, wetland within studied communes increases differently in the period of six years (from 2010 to 2016). In which, the area of wetlands in Duy Vinh, Duy Nghia commune strongly increased, 135.6 ha, 121.2 ha, respectively. Whereas the area of wetlands in Duy Thanh commune slightly increased, only 3.5 ha. The change of wetland areas from 2010 to 2016 is shown as follows:

+ Duy Thanh Commune: Land for rice cultivation (BIV2) in the year 2016 increased by 3.54 ha compared to the year 2010 because of the conversion from 0.43 ha of other annual lands, 3.18 ha of unused plain land, 0.93 ha of sedimentation land. In addition, aquaculture land (BIII1) increased 6.84 ha because of the conversion from 0.5 ha of perennial land; 3.7 ha of rivers, canals, streams; 0.31 ha of unused plain land, and 2.33 ha of other land use types to renovate nine ponds in the northern part of the Bara bridge. Rivers, canals, and streams (AII2) decreased by 11.59 ha because of the shifting to 3.7 ha of aquaculture land, 1.01 ha of non-agricultural land to build a high technology farm, 1.5 ha of unused plain land, and 5.38 ha of shrimp ponds in the north of Bara Bridge. The land area with specialized water surface (AII10) decreased by 6.11 ha compared to 2010 due to the conversion to other land use types, including the conversion to paddy land in An Lac village. Wetlands with mangrove forests (AI9) decreased by 1.34 ha mainly due to the conversion to aquaculture land.

+ Duy Vinh Commune: Land for rice cultivation (B IV 2) in the year 2016 increased by 22.03 ha due to the land consolidation, including 4.15 ha of public purpose land, 1.62 ha of unused plain land and 18.81 ha of other lands. Aquaculture land (BIII1) increased by 23.93 ha because of the conversion from rivers, canals, streams. Rivers, canals, and streams (AII2) increased by 37.46 ha, and land with specialized water surface (AII10) increased by 0.14 ha according to the new inventory map. Wetlands with mangrove forests (AI9) increased 0.88 ha because of newly planted mangrove to prevent landslide in the area north of Tra Dong.

+ Duy Nghia Commune: The area of rice cultivation (BIV2) decreased by 17.66 ha, mainly due to the conversion to 12.98 ha of other annual crops, 0.59 ha of land with the specialized water surface. Land for aquaculture (BIII1) and land for rivers, canals, streams (AII2) decreased by 2.96 ha and 144.91 ha, respectively because of the conversion to public purpose land to build storm shelters for fishing boats. Land with specialized water surface (AII10) decreased by 8.98 ha due to receiving from rice land 0.59 ha and shifting to other causes of 9.57 ha. Wetlands with mangroves forests (AI9) decreased by 4.1 ha due to conversion to aquaculture land and public purpose land to build storm shelters for Hong Trieu fishing boats.

\subsection{Evaluation effectiveness of wetland in Duy Xuyen district}

\subsubsection{The economic efficiency of wetland}

It is necessary to determine the economic efficiency of wetland in both respects, including the use value and nonuse value of the wetland (Barbier, 1997; Turner, 2000). Through surveys, interviews, and studies of secondary data, the prominent and significant economic value of wetlands in the identified study area were assessed. In general, each type of wetland has its own corresponding specific economic significance (Table 5). Based on the results of the survey, holistic assessment approach and variety of assessment methods to estimate the economic value of wetlands in the study area were applied. In particular, the market price approach was applied to calculate direct use values, and the randomized price approach was applied to estimate the mean value of the willingness of payment to preserve the biodiversity value of wetland. 
Table 5. The crucial economic value of wetland in Duy Xuyen district

\begin{tabular}{|c|c|c|c|c|c|}
\hline \multirow[b]{2}{*}{ No. } & \multirow[b]{2}{*}{ Code } & \multirow[b]{2}{*}{ Type } & \multirow[b]{2}{*}{ Sub-type } & \multicolumn{2}{|c|}{ Important economic value } \\
\hline & & & & Direct use value & $\begin{array}{l}\text { Indirect use } \\
\text { value }\end{array}$ \\
\hline 1 & A I 9 & $\begin{array}{l}\text { Wetlands with mangrove } \\
\text { forests, coconut water }\end{array}$ & $\begin{array}{l}\text { Coconut water } \\
\text { forest }\end{array}$ & $\begin{array}{l}\text { The value of tourism } \\
\text { services and exploitation } \\
\text { from products of coco- } \\
\text { nut water forest }\end{array}$ & \multirow{4}{*}{$\begin{array}{l}\text { The value of } \\
\text { biodiversity } \\
\text { conservation }\end{array}$} \\
\hline $\begin{array}{l}2 \\
3\end{array}$ & $\begin{array}{l}\text { A II } 2 \\
\text { A II } 10\end{array}$ & $\begin{array}{l}\text { Rivers, canals, streams } \\
\text { Land with the specialized } \\
\text { water surface }\end{array}$ & Fisheries & $\begin{array}{l}\text { Value of exploiting } \\
\text { aquatic resources }\end{array}$ & \\
\hline 4 & B III 1 & Aquaculture land & Aquaculture & Value of shrimp farming & \\
\hline 5 & B IV 2 & Rice land & Specialized in rice & $\begin{array}{l}\text { The value of rice pro- } \\
\text { duction in two crops }\end{array}$ & \\
\hline
\end{tabular}

Table 6. The total economic value of wetland in the study area

No. Economic value
Total economic val- ue/year (VND)

Percentage (\%)

$\begin{array}{ll}\text { 1. Direct use value } \\ 1.1 & \text { The value of rice production in two crops } \\ 1.2 & \text { The value of shrimp farming } \\ 1.3 & \text { The value of exploiting aquatic resources } \\ 1.4 & \text { The value of exploitation from products of coconut } \\ 1.5 & \text { water forest }\end{array}$

The total value of direct use value

2. Indirect use value

The value of biodiversity conservation

\section{Total economic value}

Table 6 shows that the total economic value of wetlands in the study area has both direct and indirect use value, but the scale of each value is different. The direct use value reached 41,276,949,102 VND per year, accounting for $99.61 \%$ of the total economic value of the wetland, the indirect use value accounted for only $0.39 \%$, reaching $168,855,000$ VND in a year. In which, shrimp farming value reached $17,848,350,000 \mathrm{VND}$ per year as the most considerable proportion of the total economic value of wetland, accounting for $43.07 \%$. The value of two-crop rice reached $13,160,294,000$ VND per year, accounting for $31.76 \%$ as the second most substantial proportion of the total economic value of wetland. The value of exploiting marine resources reached 9,061,000,000 VND per year, accounting for $21.87 \%$, ranking as the third in the overall economic value of the wetland. As can be seen in term of area scale, two-crop rice production area $(650.05$ ha) is 4.9 times higher than the aquaculture area (132.21 ha), but the economic value is lower (only $31.76 \%$ ). The analytic data shows that the direct economic value of shrimp farming is $135,000,000 \mathrm{VND} /$ ha/year, whereas the direct economic value of two-crop rice production is only 20,245,050 VND/ha/year. Accordingly, in term of the value scale, the direct economic value of shrimp farming was 6.7 times higher than the value of two-crop rice production. It means that the economic benefit of shrimp farming is one of the critical values in using wetland. Although the economic efficiency of two-crop rice

\begin{tabular}{rr}
$13,160,294,752$ & 31.76 \\
$17,848,350,000$ & 43.07 \\
$9,061,000,000$ & 21.87 \\
$1,159,304,350$ & 2.80 \\
$48,000,000$ & 0.12 \\
$\mathbf{4 1 , 2 7 6 , 9 4 9 , 1 0 2}$ & $\mathbf{9 9 . 6 1}$ \\
$162,855,010$ & 0.39 \\
\hline $\mathbf{4 1 , 4 3 9 , 8 0 4 , 1 1 2}$ & $\mathbf{1 0 0}$
\end{tabular}

production is lower than shrimp farming, it is a traditional production that is indispensable to local farmers.

The value of exploiting products from coconut water forest reached 1,159,304,000 VND per year, accounting for $2.8 \%$, ranking as the fourth in the total economic value of the wetland. The value of harvesting from coconut water was $66,665,000 \mathrm{VND} / \mathrm{ha} /$ year and 3.3 times higher than the value of two-crop rice production $(20,245,050$ $\mathrm{VND} /$ ha/year). It was found that the economics of coconut water was higher than that of wet rice. However, the area of coconut water forest in studied area was small. Despite its high economic value, the role of coconut water forest has not been noticed yet by local people as well as administrative managers. Therefore, the area of water coconut forest was narrowed and converted to aquaculture land.

The value of tourism services counted for $0.12 \%$ of the total economic value of the wetland. It occupied as small proportion because this exploitation type highly depends on objective factors such as weather condition or tourist arrivals. The tourism services predominate only in Duy Vinh commune with Tra Nhieu Ecological Tourist Area. However, these values also show the diversity of roles and functions that wetlands bring to local people.

Despite the small size and proportion of total economic value, the presence of indirect use value $(0.39 \%)$ has 
shown the existence of diverse conservation values in the attitudes and perceptions of local people. It means that people are willing to put money to maintain the biodiversity with the specific value of wetlands, which help local administration gets the strategy in proposing conservation policies to efficiently utilize wetland resources, bringing the most significant benefits to the community and society.

\subsubsection{The social and environmental value of wetland}

Table 7. The social and environmental value of wetland types in Duy Xuyen district

\begin{tabular}{|c|c|c|c|c|c|c|}
\hline No. & Criteria & $\begin{array}{l}\text { Two-crop } \\
\text { rice } \\
\text { production }\end{array}$ & $\begin{array}{l}\text { Shrimp } \\
\text { farming }\end{array}$ & $\begin{array}{l}\text { Aquatic } \\
\text { resources }\end{array}$ & $\begin{array}{l}\text { Tourism } \\
\text { services }\end{array}$ & $\begin{array}{l}\text { Coconut } \\
\text { water } \\
\text { production }\end{array}$ \\
\hline & \multicolumn{6}{|l|}{ Social value } \\
\hline 1 & Attracting labor & 3 & 4 & 2 & 1 & 2 \\
\hline 2 & Ability to sell products & 3 & 4 & 4 & 3 & 2 \\
\hline 3 & Access to capital & 4 & 3 & 1 & 2 & 3 \\
\hline \multirow[t]{2}{*}{4} & Technical accessibility & 4 & 4 & 1 & 1 & 2 \\
\hline & \multicolumn{6}{|l|}{ Environmental value } \\
\hline 5 & Ability in against storms and floods & 2 & 1 & 1 & 1 & 4 \\
\hline 6 & $\begin{array}{l}\text { Ability in maintaining and protecting of } \\
\text { soil }\end{array}$ & 3 & 2 & 4 & 3 & 4 \\
\hline 7 & Water quality deterioration & 3 & 4 & 3 & 1 & 1 \\
\hline 8 & Biodiversity control & 3 & 2 & 1 & 3 & 4 \\
\hline 9 & Impacts to environment & 4 & 3 & 3 & 2 & 3 \\
\hline
\end{tabular}

$($ High=4; Medium=3; Low=2; Very low=1)

In this research, the social and environmental value of wetland were assessed based on the percentage agreement of surveyed households (Rating $\geq 70 \%$ : High; Rating $\geq 50 \%$ to $70 \%$ : Medium; Rating $\geq 30 \%$ to $50 \%$ : Low; Rating $<30 \%$ : Very low).

The results from Table 7 show that the social and environmental effects between wetland use types are entirely different, or even among criteria in the same wetland use type. As the social aspect, shrimp farming is the most effective, followed by two-crop rice production; whereas the lowest social efficiency is tourism services. However, for environmental aspect, shrimp farming gets the lowest environmental efficiencies, whereas exploiting the products from the coconut water has the highest environmental ability, showing the significance of coconut water forest to the local environment.

\subsection{Solutions to increase the effectiveness of wetland utilization in Duy Xuyen district}

Based on the analytical results, the number of recommendations is proposed to increase the effectiveness of wetland utilization, including:

- The local administration should promote the existing community ecotourism in Tra Nhieu Ecological Tourism Area to increase the use of wetland resources for tourism development. Also, it requires developing more different community tourism by exploiting the strengths of wetlands to create special tourism products, such as sandy beaches, coconut water forests. Finding new livelihoods will help local people earn more stable income than now. Importantly, natural resources would not be exploited as the eradicative way, whereas the protection awareness of local people could be enhanced.
- Mangrove forest restoration (especially coconut water forest): it requires to protect the existing mangrove forest area, and regenerate mangrove forests in degraded aquaculture areas, damaged shrimp ponds, especially in areas prone with high erosion such as river estuaries and low tidal regions for growing mangroves.

- Community-based biodiversity conservation: Management and conservation of biodiversity in general and wetland biodiversity in particular, based on local communities could create the close relationship between people and nature, which helps manage and use natural resources stably and sustainablmannery. Therefore, the conflicts between economic, social development and environmental protection could be restricted. In addition, biodiversity and traditional values of natural resources could be preserved, which minimize impacts on biodiversity and natural environment.

- The local administration should attach natural resource management solutions to such importance planning on land use. Therefore, it is necessary to construct necessary infrastructure: main roads, electricity systems, canals, etc., for developing production of aquaculture and tourism. Besides, it requires having insurance policies for local people who directly invest in aquaculture production activities with high cost and risk.

- The local administration should organize more training courses to transfer scientific advice and apply great techniques for farmers on fishing, rice-producing or making tourism productions from coconut water forest. Raising awareness of the community and active participation of people in the conservation of biodiversity, preservation values of the wetland. 


\section{Conclusions}

The result shows the total area of wetlands in Duy Xuyen are mainly distributed in three communes: Duy Thanh, Duy Nghia, and Duy Vinh, with an area of 1,391.95 ha, accounting for $40.58 \%$ of the total natural area of the three communes. It indicates that there are five types of wetlands in the study area, including Wetlands with mangrove forests, coconut water; Wetlands with rivers, canals, streams; Land with specialized water surface; Aquaculture land; Rice land. The wetland areas in Duy Xuyen district noticeably decreased in the period from 2010 to 2016.

The total economic value of the wetland in the study area includes both direct and indirect use values. However, the scale of each value is different. The direct use value reached 41,276,949,102 VND/year, accounting for $99.61 \%$ of the total economic value of the wetland. Whereas, the indirect use value occupied only $168,855,000 \mathrm{VND} /$ year, accounting for $0.39 \%$ of the total economic value of the wetland. As direct use value, the scale of each use value is also entirely different, as following order: the value of shrimp farming, the value of two-crop rice production, the value of exploiting aquatic resources, the value of exploitation from products of coconut water forest, and the value of tourism services.

Social and environmental economic values of wetland uses are entirely different or even among criteria in the same wetland use type. As the social aspect, shrimp farming is the most effective, followed by two-crop rice production; whereas the lowest social efficiency is tourism services. However, for environmental aspect, shrimp farming gets the lowest environmental efficiencies, whereas exploiting the products from the coconut water has the highest environmental ability, showing the significance of coconut water forest to the local environment.

\section{References}

[1] Barbier, E.B., Acreman, M. and Knowler, D. (1997), Economic valuation of wetlands: a guide for policymakers and planners, http://biodiversityeconomics.org/pdf/topics-0201.pdf (5/4/2004).

[2] Tran Thanh Duc (2017), Statistical Processing in Land Management, Hue University of Agriculture and Forestry.

[3] Tran Dinh Lan, Nguyen Thi Minh Huyen, Le Quang Dung, Nguyen Thi Thu (2013), The proposed method for evaluating the economic value of marine ecosystems in Vietnam. Journal of Science and Technology Sea Technology, Volume 13, No. 4.

[4] Dinh Duc Truong (2008), Assessment of economic value for wetland resource management - applied in $\mathrm{Ba}$ Lat estuarine wetland area, Nam Dinh province. National People's Congress.

[5] Hoang Van Thang, Le Dien Duc, CRES (2006), Vietnam Wetlands Classification System, Environmental Protection Program Mekong Wetlands Biodiversity Conservation Program.

[6] Turner, R.K., Van den Bergh, J.C.J.M., Soderqvist, T., Barendregt, A., van der Straaten, J., Maltby, E. and van Ierland, E.C. (2000), Ecological-economic analysis of wetlands: scientific integration for management and policy, Ecological Economics, 35(1), $7-23$.

[7] Vietnam Environment Protection Agency (2005), Overview status of wetlands in Vietnam after 15 years of implementing the Ramsar Convention, Hanoi, Vietnam. 